\title{
And the winners are ... The official results of the 2010 ACRL elections
}

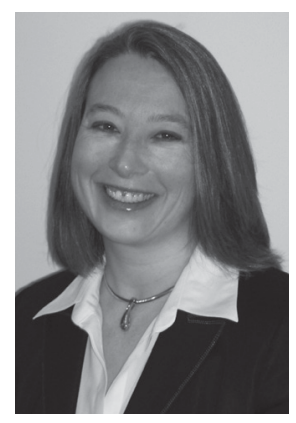

Lisa Janicke Hinchliffe

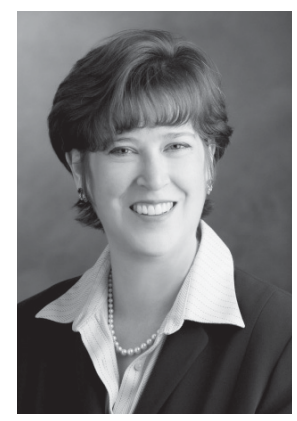

Joyce L. Ogburn
Lisa Janicke Hinchliffe, associate professor and coordinator for information literacy services at the University of Illinois at UrbanaChampaign, is the 73rd president of ACRL.

"When I stood for election to this position, I spoke repeatedly of the important of advocacy, continuous professional learning, and organizational agility. Our venues for advocacy include not only local and institutional settings, but also higher education and governmental policy writ large. Continuous professional learning is consistently one of the areas that members value highly about ACRL, and we are all challenged individually and collectively to continue to improve and expand our skills as the information, education, and research environments in which we work evolve. As a member-driven organization, ACRL seeks to be agile and nimble in responding to today's challenges and tomorrow's opportunities. My goal is to offer expanded opportunities for members to pursue their interests in meaningful ways and to benefit from their personal connections with the association.

"As I begin my presidential year, I am excited about the value of academic libraries project [which] began under Lori Goetsch's leadership. I look forward to sharing the findings from ACRL's work in this area and determining how we can continue to build the evidence base that documents our effectiveness and influence. As ACRL embarks on a process to create a new strategic plan in the coming year, the value project will inform our discussions about the future of ACRL and the profession and assist in identifying our future strategic priorities and initiatives.

"It is an honor and privilege to serve as the President of ACRL. Even in these challenging times of economic and social change, I envision a bold and exciting future for academic librarians as our institutions reinvent themselves in today's knowledge and information society. I look forward to collaborating with the Board, ACRL staff, and members as we work together to ensure that ACRL continues to develop and flourish as an organization."

As president, Hinchliffe will preside over the ACRL Board of Directors and ACRL Executive Committee, and plan ACRL's major program at the 2011 ALA Annual Conference. She will work with the ALA president and other division presidents representing ACRL both within and outside of ALA.

From 2006 to 2009, Hinchliffe was head of the undergraduate library at the University of Illinois at Urbana-Champaign. From 1998 to 2002, she was library instruction coordinator at Illinois State University. Hinchliffe also worked at Parkland (Community) College, where she served as reference librarian from 1996 to 1998.

Her activities in ACRL include serving as chair of the Blog Advisory Board (200809), and cochair of the National Conference Innovations Group (2007-09). She served as a member of the Information Literacy 
Competency Standards Review Task Force (2007-08), and as chair of the Instruction Section (IS) Nominating Committee (2007-09). Hinchliffe was a member of the Institute for Information Literacy Executive Committee (2006-07, 2002-03), Institute for Information Literacy Undergraduate Student Surveys Group (2004-07), and Institute for Information Literacy Best Practices Advisory Panel (2000-03). She was chair of the Instruction Section (IS) (2005-2006), member-at-large (2000-03), and secretary (1998-99). Her service on IS committees includes the Dudley Award Subcommittee (2006-07), Research and Scholarship Committee (1999-2000), Skill Areas for Instruction Librarians Task Force (1998-99), Membership (1995-97), and the Name Change Implementation Task Force (1995-96). She also chaired the Information Literacy Advisory Committee (2006-07 and 2000-02). Hinchliffe served on the National Conference Contributed Papers Subcommittee (2005-07) and Preconferences Subcommittee (2001-03). She was a member of the First-Year Experience Task Force (2003-04) and Focus on the Future Task Force (2001-03). She served on the Distance Learning Section (DLS) Guidelines Committee (1999-2001) and chaired the Community and Junior College Libraries Section (CJCLS) Technology Committee (1997-98).

Hinchliffe's work with state and regional associations includes service in the Consortium of Academic and Research Libraries in Illinois where she has been a member of the Public Services Working Group since 2006. She is currently a member of the Instruction Librarians Group (2006-present), which is part of the Center for Library Initiatives, Committee on Interinstitutional Cooperation (Big 10+). She served on the LOEX Advisory Board (2000-07). Hinchliffe was a member of the Association of Research Libraries Task Force on Library Roles in Enhanced Environments for Teaching and Learning (2006), Library Assessment Conference Planning Committee (2005-06), and Learning Outcomes Working Group (2003-05). She served on the Illinois Library Association
Awards Committee (2001-03) and the Illinois Association of College and Research Libraries, where she chaired the 2001 Program Planning Committee (2000-01) and the 2000 Preconference Program Planning Committee (1999-2000).

Her publications include coauthorship of "Teaching the Teachers: Developing a Teaching Improvement Program for Academic Librarians," The Expert Library: Staffing, Sustaining, and Advancing the Academic Library in the 21st Century (forthcoming, ACRL); "The Future of Information Literacy," The Information Literacy Instruction Handbook (ACRL, 2008); and coauthor of "Beyond Classroom Construction and Design: Formulating a Vision for Learning Spaces in Libraries," Reference and User Services Quarterly (2005).

Hinchliffe received the University of Illinois Library School Alumni Association Leadership Award (2003), ONLINE Word Best Practice Award (2000), and Jane B. and Robert B. Downs Professional Promise Award (1995). She was selected to participate in the Frye Leadership Institute (2003) and UCLA Senior Fellows Program (2003) and was elected to Beta Phi Mu (1994).

She received her masters of education and masters of library and information science from the University of Illinois at Urbana-Champaign. She earned her bachelor of arts from the University of St. Thomas (Minnesota).

Joyce L. Ogburn, university librarian and director of the University of Utah Marriott Library, has been elected vice-president/ president-elect of ACRL.

"Being chosen to lead ACRL as vicepresident/president-elect is the highlight of my career. I am enormously grateful for the confidence of the members in my leadership skills and will do my utmost to advance ACRL's initiatives and programs. I follow in the footsteps of terrific people and will greatly enjoy serving with Lisa Hinchliffe, our incoming president, and Lori Goetsch, who will become past president. I know that 
over the next few years ACRL will be supported by thoughtful and innovative leaders.

"ACRL remains a vital and strong organization devoted to sustaining academic librarianship in these turbulent times that are fraught with challenge but equally full of opportunities. Supporting and serving ACRL is an investment in an exciting and rewarding future. ACRL and our academic libraries and librarians will continue to serve the broad interests of research and learning through its ambitious agenda led by our devoted members. I will engage us all in seeking the path to a future we all can believe in and look forward to with great anticipation and eagerness. ACRL is just the right organization for getting us there. I am honored to be involved with such a great association and can't wait to get started in my new role."

From 1999 to 2005, Ogburn was associate director at the University of Washington. Prior to that, she was assistant university library at Old Dominion University (1996-99). She served as chief acquisitions librarian at Yale University (1991-96), and was acquisitions librarian at Penn State University (1984-91).

Her activities in ACRL include serving as the scholarly communication column editor for CERL News (2006-09), as cochair of the Scholarly Communications Committee (200608), and as a member of the Choice Editorial Board (2000-04). She was the founder and editor of ANSSWeb (1995-2003), and was chair of the Anthropology and Sociology Section (ANSS) (1997-98). Joyce also served as editor of ANSS Currents (1996-97).

Her ALA activities include serving as chair of the ALCTS Chief Collection Development Officers of Large Research Libraries (200405), and as chair of the ALCTS Acquisition of Library Materials Section Education Committee (1991-92). She was a member of the ALA Library Education Assembly (1990-92), and was chair of the ALCTS Education Committee (1990-91).

Ogburn's work with state and regional associations includes serving on the Greater Western Library Alliance Board of Directors (2009-present), and serving on the Association of Research Libraries Scholarly Communications Steering Committee (2008-present). She is a member of the Center for Research Libraries Board of Directors (2007-present), and she served on the SPARC Steering Committee (2005-07). She was also a member of the American Anthropological Association Librarians Advisory Group (2001-05).

Ogburn was a UCLA Senior Fellow (2001), and was elected to Phi Beta Kappa (1978).

Her publications include author of, "Moderately Risky Business: Challenging Librarians to Assume More Risk in an Era of Opportunity," Risk and Entrepreneurship in Libraries: Seizing Opportunities for Change (ALA/ALCTS), 2009; author, "Defining and Achieving Success in the Movement to Change Scholarly Communication," Library Resources and Technical Services, 2008; and coauthor, Establishing a Research Agenda for Scholarly Communications: A Call for Community Engagement (ACRL), 2007.

Ogburn received her master's of library science from the University of North Carolina at Chapel Hill. She received her master's degree in Anthropology from Indiana University, and earned her bachelor of arts degree in Anthropology from the University of North Carolina at Greensboro.

\section{ACRL}

Vice-President/President-Elect: Joyce L.

Ogburn (1529); Frank D'Andraia (900).

\section{ACRL Board}

Director-at-Large (4-year term): Mark Emmons (1099); John H. Pollitz (1090).

Director-at-Large (4-year term): Kenley Neufeld (980); Mary Ann Sheble (1233). Councilor (3-year term): Susan M. Allen (1102); Maggie Farrell (1184).

\section{African American Studies Librarians Section (AFAS)}

Vice-chair/Chair-elect: Rebecca Hankins (40); Gennice W. King (23).

Secretary: Shauna Collier (60); Write-in candidate (1). 
Member-at-Large (2-year term): Angela Gooden (20); Malaika Grant (43).

\section{Anthropology and Sociology Section} (ANSS)

Vice-chair/Chair-elect: Terrence W. Epperson (55); Gabrielle Margaret Toth (45)

Member-at-Large (2-year term): Juliann Couture (28); Annie Paprocki (68).

\section{Arts Section}

Vice-chair/Chair-elect: Megan Smith-Heafy (126); Write-in candidate (0).

\section{Asian, African, and Middle Eastern Section (AAMES)}

Vice-chair/Chair-elect: Binh P. Le (47); Writein candidate (2).

Member-at-Large (2-year term): Hong Cheng (32); Tao Yang (35); Write-in candidate (0).

\section{College Libraries Section (CLS)}

Vice-chair/Chair-elect: Frank Quinn (118); Celia E. Rabinowitz (392).

Secretary: Eric A. Kidwell (234); Stacy L. Voeller (252)

Member-at-Large (2-year term): Carolyn Carpan (268); Ethelle S. Bean (214).

\section{Community and Junior College Libraries Section (CJCLS)}

Vice-chair/Chair-elect: B. Nan Schichtel (192); Write-in candidate (1).

Secretary: Carl A. Antonucci (188); Write-in candidate (1)

\section{Distance Learning Section (DLS)}

Vice-chair/Chair-elect: Samantha Schmehl Hines (262); Write-in candidate (3).

Secretary/Archivist: Timothy Peters (175); Brian Arnold Hickam (90).

Member-at-Large (2-year term): Alice Daugherty (257); Write-in candidate (4).

\section{Education and Behavioral Sciences Section (EBSS)}

Vice-chair/Chair-elect: Vanessa J. Earp (83); Sally Neal (122)
Member-at-Large (2-year term): Catherine Helen Michael (89); Cheryl Goldenstein (110).

\section{Instruction Section (IS)}

Vice-chair/Chair-elect: Stephanie A. Michel (471); Merinda McLure (347)

Secretary: Anne-Marie Deitering (465); Mireille Djenno (333)

Member-at-Large (2-year term): Meghan Sitar (360); Mark Szarko (409); Merinda Kaye Hensley (403); Amy L. Deuink (266).

\section{Law and Political Science Section} (LPSS)

Vice-chair/Chair-elect: Chad M. Kahl (58); Leslie R. Homzie (45).

Member-at-Large (2-year term): Brian E. Coutts (57); Sidney D. Lowe (42).

\section{Literatures in English Section (LES)}

Vice-chair/Chair-elect: Faye Christenberry (72); Shawn Martin (38).

Secretary: Tim Hackman (50) Elected by lot; Aline Soules (50).

Member-at-Large (1-year term): Melissa S. Van Vuuren (72); Laura Sue Fuderer (33).

\section{Rare Books and Manuscripts Section} (RBMS)

Vice-chair/Chair-elect: Mike Kelly (168); R. Arvid Nelsen (148)

Member-at-Large (3-year term): Nina Marie Schneider (172); Jennifer Hain Teper (134).

Science and Technology Section (STS)

Vice-chair/Chair-elect: Maribeth Slebodnik (207); Nora A. Hillyer (76).

Publicity Officer: Norah Xiao (149); Steven M. Adams (127)

Member-at-Large (2-year term): William Simpson (122); Maxine Schmidt (151)

\section{Slavic and East European Section} (SEES)

Vice-chair/Chair-elect: Liladhar R. Pendse (39); Write-in candidate (0).

(continues on page 333) 
L. Clements Library in Ann Arbor, Michigan. This collection documents the political, educational, agricultural, and social activities of Norton Strange Townshend (181595), his wife (educator Margaret Bailey Townshend), and several generations of related families in northern Ohio and elsewhere. Townshend had a long and multifaceted career, which included antislavery activism, political involvement at the local level and in the U.S. House of Representatives, work on the Underground Railroad, a role as a medical inspector in the Civil War, and advocacy of scientific training for farmers. The latter earned him the nickname "the father of agricultural education in the United States" and allowed him to shape Ohio State University as a found and the institution's first professor of agriculture. In addition to primary sources such as correspondence, diaries, published and unpublished writings, ephemera and photographs, the collection contains 34 letters from Townshend's friend and mentor, Salmon P. Chase.
The E.H. Duckworth Photographic Ar-

chive, containing more than 5,000 photos documenting Nigerian life in the decades just before independence, has been acquired by Northwestern University Library's Melville J. Herskovits Library of African Studies. A British civil servant, Duckworth spent more than 20 years in Nigeria, where he was editor of and frequently a photographer for The Nigeria Magazine, which was founded to promote Nigerian national identity. His papers are now housed in the Bodleian Library of Commonwealth and African Studies at Rhodes House, Oxford, but the photographs-plus several hundred glass lantern slides and thousands of original negatives-have spent most of the past 40 years packed up in the travelling trunks in which Duckworth shipped them back to England. The archive complements other colonial African photo collections in the Herskovits Library-notably the Winterton Collection of East African Photographs-in that it records images intended for an African, rather than colonial, audience. $\boldsymbol{n}$

("Signs of success," continued from page 302)

what we will be able to do with digital signage in the future convinces us that we made the right choice when we turned our backs on traditional signage and made digital signage an integral part of our mission of teaching, research, and service.

\section{Notes}

1. For a video gallery of current and past signs, visit ucmercedlibrary.info/digitalsignage/digital-signage-gallery.html.

2. ucmercedlibrary.info/on-display /digital-signage.html. $n$
("And the winners are..." cont. from p. 321)

\section{University Libraries Section (ULS)}

Vice-chair/Chair-elect: Jan Kemp (379); Carol

G. Hixson (634).

Member-at-Large (3-year term): Michele M.

Reid (559); Rebecca Bernthal (461); Rachel Augello Erb (539).

\section{Western European Studies Section} (WESS)

Vice-chair/Chair-elect: James P. Niessen (55);

Gail P. Hueting (57).
Secretary: Karen Green (38); Jonathan C. Marner (60).

Member-at-Large (1-year term): Jeff Staiger (44); Heidi Madden (54).

\section{Women's Studies Section (WSS)}

Vice-chair/Chair-elect: Pamela Mann (64); Chimene Elise Tucker (47).

Secretary: Erin Gratz (24); Heather Lee Tompkins (89).

Member-at-Large (2-year term): Phyllis Hol-

man Weisbard (109); Write-in candidate (1). $n$ 